\title{
Cadastral valuation of lands dedicated to perennial plantings: features and practice
}

\author{
Kirill Zhichkin ${ }^{1}$, Vladimir Nosov ${ }^{2, *}$, Aleksandra Lakomiak $^{3}$, and Lyudmila Zhichkina ${ }^{4}$ \\ ${ }^{1}$ Samara State Agrarian University, Department of Economic Theory and Economics of AIC, 446442, \\ Kinel, Russian Federation \\ ${ }^{2}$ K.G. Razumovsky Moscow State University of Technologies and Management, Department of \\ Economics and Management, 109004, Moscow, Russian Federation \\ ${ }^{3}$ Wroclaw University of Economics, Department of Financial Accounting and Control, 53-345, \\ Wroclaw, Poland \\ ${ }^{4}$ Samara State Agrarian University, Department of Land Management, Soil Science and Agrochemistry, \\ 446442, Kinel, Russian Federation
}

\begin{abstract}
The article considers the issue of cadastral valuation of agricultural lands used for perennial plantations (orchards). Unlike other agricultural crops, orchard crops occupy the land for a long period of time, therefore, the planting expenditures are capital. The purpose of the study is to define the features and adapt the existing methodology for cadastral valuation of lands occupied by orchards considering the actual return on the evaluated land plot and the distance factor that affects the increase in cost and decline in return depending on the location of the plot in relation to the main markets. The example (plots are located in the Bezenchugsky district of the Samara region) shows that the costs of orchard plots are 2.73 and 2.93 rubles per square meter, respectively. Quality characteristics of the first plot are better, but it is located further from the centre of the region.
\end{abstract}

\section{Introduction}

Land plots of conditionally permitted use are agricultural lands unfit for tillage but used for cultivation of technical crops, perennials, berries, tea, grape and rice [1-3].

Perennials of the Samara region are represented by relatively small industrial orchards and berry-fields (except for the horticultural societies that are not considered in this paper). The real estate market lacks of such objects, so it is not possible to estimate the market value using the comparison approach $[4,5]$.

\section{Methods and Materials}

In this case, we can consider the formation of the market value of lands from two angles:

\footnotetext{
*Corresponding author: novla@list.ru
} 
- using the cost approach, similar to the principle of estimation of lands of the third and fourth types of permitted use;

- using the income approach [6-8].

We can evaluate land plot occupied by orchards using the same algorithm as in the evaluation of agricultural lands, where there is a need to determine:

- using the cost approach, similar to the principle of estimation of lands of the third and fourth types of permitted use;

- using the income approach [6-8].

We can evaluate land plot occupied by orchards using the same algorithm as in the evaluation of agricultural lands, where there is a need to determine:

- the yield per unit;

- the product value;

- the costs per unit of cultivation and maintenance of soil fertility;

- the unit revenue;

- the unit rent (entrepreneur's expenditures and profit excluded)

- the unit cadastral value of lands occupied by perennials;

- the cadastral value of land plots [9-12].

The general formula for calculation of the value of the land occupied by the orchard is:

$$
U C V=\text { Income } / K_{o}
$$

where $K_{o}$ is the capitalization ratio.

$$
\text { Income }=Y \cdot P r-C o s t-E P
$$

where Income is the net income for the crop, rubles;

$Y$ - yield during the heavy bearing season, rubles/ha;

$\operatorname{Pr}$ is the sale price, rubles $/ \mathrm{kg}$;

Cost - costs of cultivation and harvesting during the economic life period, rubles/ha;

$E P$ - entrepreneur's average profit in agriculture, rubles/ha [13-18].

\section{Results and Discussion}

Evaluating lands dedicated to perennial plantings, we need to consider the time factor that reflects the period of expenditures uncovered by production. For example, modern apple orchards have a 15-18 years economic life period, and it takes trees 4-6 of those years to fruit. The last years of this period are characterized by a decrease in yields. At the end of the economic cycle of the orchard, there is a need to remake it or to eliminate it in order to vacate the land. This approach considers the income generated by the soil fertility and fixed assets, which include fruit trees, and results in an overvaluation of land [19-22].

Table 1. Costs and revenues from raspberry cultivation in the Samara region, rubles.

\begin{tabular}{|l|c|c|}
\hline \multirow{2}{*}{\multicolumn{1}{|c|}{ Article }} & \multicolumn{2}{c|}{ Costs } \\
\cline { 2 - 3 } & per 1.4 ha & per 1 ha \\
\hline Electricity & 18750.00 & 13392.86 \\
\hline Fertilizers & 2352.00 & 1680.00 \\
\hline Plant protection agents & 9240.00 & 6600.00 \\
\hline Combustibles and lubricants & 41931.00 & 29950.71 \\
\hline Salary & 178901.00 & 127786.43 \\
\hline Allowance & 62615.35 & 44725.25 \\
\hline Other & 36000.00 & 25714.29 \\
\hline TOTAL & 349789.35 & 249849.54 \\
\hline 2011 gross yield & 64.00 & Cwt \\
\hline
\end{tabular}




\begin{tabular}{|l|c|c|}
\hline Price & 75.00 & Rubles $/ \mathrm{kg}$ \\
\hline Revenue & 480.00 & Thousand rubles \\
\hline Revenue per 1 ha & 342.86 & Thousand rubles \\
\hline
\end{tabular}

Tables 1 and 2 show the generalized economic calculation of a 1.4 ha raspberry field set out on chernozem soil (based on data for farms using the modern Polish technology for growing raspberry and strawberry). The data is at 2011, however, considering the fact that the plantings were watered, we can assume that yield was the same in the dry 2010 year.

Table 2. Calculation of the value of land occupied by perennials (raspberry field).

\begin{tabular}{|l|c|}
\hline \multicolumn{1}{|c|}{ Indicator } & Value \\
\hline Net income, sprinkler system depreciation included, rubles & 93007.61 \\
\hline Annual depreciation, rubles & 12500.00 \\
\hline Net income before depreciation & 80507.61 \\
\hline Net income 7 years, rubles/ha & 563553.25 \\
\hline Annual revenue to the eight-year cycle, rubles/ha & 70444.16 \\
\hline Capitalization ratio & 0.10 \\
\hline Land value, rubles/ha & 704441.56 \\
\hline Land value, rubles/square meter & 70.44 \\
\hline
\end{tabular}

Raspberry bears fruit in the second year after planting. Plantation works for 8 years. Irrigation is required.

When the 5-6-years production cycle is ended, the arable land is sowed with other field crops.

It is better if the preceding crop is spring cereal or if the land was left fallow.

Table 3 presents the calculation of the irrigation system depreciation. The calculation is similar to the one done when creating an irrigation system for an orchard [23-25].

Table 3. Calculation of the depreciation allowance.

\begin{tabular}{|l|c|}
\hline \multicolumn{1}{|c|}{ Indicator } & Value \\
\hline Orchard area, square meters & 2000000 \\
\hline Expenditures for hydraulic structures, rubles. & 20000000 \\
\hline Unit costs, rubles/ square meter & 10 \\
\hline The berry field area, square meters & 10000 \\
\hline Sprinkler system value, rubles & 100000.00 \\
\hline Depreciation period, years & 8 \\
\hline Annual depreciation flow, rubles & 12500.00 \\
\hline
\end{tabular}

The obtained result ( 70.44 rubles/square meter) exceeds the base land cost (before making a raspberry field) by several times, which confirms that the impact of fixed assets on the value of occupied land is significant.

We also offer to consider a similar example of calculation for an apple orchard (an intensive technology for dwarf rootstocks).

It bears fruit in the fourth year after planting. The orchard works for 15 years (since planting). Irrigation is required.

When the 5-6-years production cycle is ended, the arable land is sowed with other field crops. According to Table 4, it is better if the land is left fallow for a period of time.

Table 4. Costs and revenues from cultivation of an apple orchard in the Samara region, rubles.

\begin{tabular}{|l|c|c|}
\hline \multirow{2}{*}{ Atricle } & \multicolumn{2}{|c|}{ Costs } \\
\cline { 2 - 3 } & 138 ha land plot & Per 1 ha \\
\hline Electicity & 86810 & 629 \\
\hline Fertilizers & 200000 & 1449 \\
\hline
\end{tabular}




\begin{tabular}{|l|c|c|}
\hline Plant protection agents & 2111896 & 15304 \\
\hline Combustibles and lubricants & 857808 & 6216 \\
\hline Salary & 2485205 & 18009 \\
\hline Allowance & 869822 & 6303 \\
\hline Other & 1566000 & 11348 \\
\hline TOTAL & 8177540 & 59258 \\
\hline 2011 gross yield & 15870 & $\mathrm{Cwt}$ \\
\hline Price & 20 & Rubles $/ \mathrm{kg}$ \\
\hline Revenue & 31740 & Thousand rubles \\
\hline Revenue per 1 ha & 230 & Thousand rubles \\
\hline
\end{tabular}

The result presented in Table 5 is significantly higher than the cost of land occupied by an orchard. It should also be taken into account that garden trees are classified as fixed assets, and their value is partially transferred to the land value.

Table 5. Calculation of the value of land occupied by perennials (apple orchard).

\begin{tabular}{|l|c|}
\hline \multicolumn{1}{|c|}{ Indicator } & Value \\
\hline Net income, sprinkler system depreciation included, rubles & 170742.46 \\
\hline Annual depreciation, rubles & 12500.00 \\
\hline Net income before depreciation & 158242.46 \\
\hline Capitalization ratio & 0.10 \\
\hline Land value & 1582424.61 \\
\hline Land value & 158.24 \\
\hline Net income 11 years, rubles/ha & 1740667.07 \\
\hline Annual revenue to the fifteen-year cycle, rubles/ha & 116044.47 \\
\hline Capitalization ratio & 0.10 \\
\hline Land value, rubles/ha & 1160444.72 \\
\hline Land value, rubles/square meter & 116.04 \\
\hline
\end{tabular}

As mentioned above (when calculating the value of lands of the third and fourth types of permitted use), the business value cannot be transferred to the value of land entirely.

Therefore, when calculating the value of lands of the second type of permitted use, we can use the approach similar to the one used when calculating the value of lands occupied by buildings and facilities.

Table 6. Calculation of the cadastral value of the land plot occupied by perennials in the Bezenchugsky district.

\begin{tabular}{|c|c|c|c|c|c|}
\hline Plot number & Plot location & Permitted use & Area, $\mathrm{m}^{2}$ & $\begin{array}{c}\text { The } \\
\text { code }\end{array}$ & $\begin{array}{c}\text { Distance to the } \\
\text { regional centre, } \\
\mathrm{km}\end{array}$ \\
\hline 63:12:0301002:1 & $\begin{array}{c}\text { The Samara Region., } \\
\text { Bezenchugsky district }\end{array}$ & For orchard & 87700 & 2 & 30 \\
\hline 63:12:0403004:1 & $\begin{array}{c}\text { The Samara Region., } \\
\text { Bezenchugsky district }\end{array}$ & Under orchard & 3779666 & 2 & 16 \\
\hline
\end{tabular}

In addition to the synergistic effect of the land value, there is also a need to consider the factor of distance of the land plot to the regional centre.

Hence, the total market value of a land plot of the second type of use can be calculated using the following formula:

$$
C i=1,2628 \cdot C n \cdot(1+L i)
$$

where $C_{n}$ is the market (cadastral) value of surrounding lands;

1,2628 is the synergistic effect ratio equal to the entrepreneur's profit margin; 
$L_{i}$ is the distance factor of the evaluated land plot to the regional centre.

Table 7. Calculation of the cadastral value of the land plot occupied by perennials in the Bezenchugsky district.

\begin{tabular}{|c|c|c|c|c|c|}
\hline Plot number & $\begin{array}{c}\text { Unit cadastral } \\
\text { value of a } \\
\text { vacant land } \\
\text { plot, } \\
\text { rubles/square } \\
\text { meters }\end{array}$ & $\begin{array}{c}\text { Entrepreneur's } \\
\text { profit margin, } \\
\%\end{array}$ & $\begin{array}{c}\text { Distance } \\
\text { factor, \% }\end{array}$ & $\begin{array}{c}\text { vnit cadastral } \\
\text { value of a land } \\
\text { ploccupied by prchard, } \\
\text { an } \\
\text { rubles/square } \\
\text { meters }\end{array}$ & $\begin{array}{c}\text { Cadastral value of } \\
\text { the land plot under } \\
\text { evaluation, rubles }\end{array}$ \\
\hline $63: 12: 0301002: 1$ & 1.70 & 26.28 & 0.2734 & 2.73 & 239751.16 \\
\hline $63: 12: 0403004: 1$ & 1.68 & 26.28 & 0.3828 & 2.93 & 11088187.87 \\
\hline
\end{tabular}

Tables 6 and 7 present the calculation of value of land plots of the second type of permitted use in the Bezenchugsky district.

\section{Conclusion}

The proposed methodology for cadastral valuation of agricultural lands dedicated to perennial plantings is based on the described approach. Moreover, there is a need to take account of the actual return of the land plot and the distance factor that affects the increase in cost and decline in return depending on the location of the plot in relation to the main markets. The example (plots are located in the Bezenchugsky district of the Samara region) shows that the costs of orchard plots are 2.73 and 2.93 rubles per square meter, respectively. Quality characteristics of the first plot are better, however, it is located further from the centre of the region.

\section{References}

1. E.A. Staselko, O.V. Erdniev, T.A. Balinova, U.S. Germasheva, S.A. Snagadjieva, A.V. Baryshev, IOP Conf. Ser. Mater. Sci. Eng., 663, 012050 (2019) doi: 10.1088/1757$899 \mathrm{X} / 663 / 1 / 012050$

2. K. Zhichkin, V. Nosov, L. Zhichkina, V. Zhenzebir, O. Sagina, IOP Conf. Ser. Earth Environ. Sci., 421, 022066 (2020) doi: 10.1088/1755-1315/421/2/022066

3. E. Bykowa, J. Sishchuk, ZFV, 140, 22-26 (2015)

4. T. Cay, M. Uyan, Land Use Policy, 30, 541-548 (2013) doi: 10.1016/j.landusepol.2012.04.023

5. M.J. Beckmann, Ann. Regional Sci., 5, 6-10 (1971) doi: 10.1007/BF01288108

6. A. Łakomiak, K. A. Zhichkin, BIO Web Conf., 17, 00236 (2020) doi: 10.1051/bioconf/20201700236

7. D.L. Chicoine, Land Econ., 57, 353-362 (1981) doi: 10.2307/3146016

8. H. Huang, G.Y. Miller, B.J. Sherrick, M.I. Gómez, Am. J. Agr. Econ., 88, 458-470 (2006) doi: 10.1111/j.1467-8276.2006.00871.x

9. S. Ma, S.M. Swinton, Ecol. Econ., 70, 1649-1659 (2011) doi: 10.1016/j.ecolecon.2011.04.004

10. G. Livanis, C.B. Moss, V.E. Breneman, R.F. Nehring, Am. J. Agr. Econ., 88, 915-929 (2006) doi: 10.1111/j.1467-8276.2006.00906.x

11. A.J. Platinga, D.J. Miller, Land Econ., 77, 56-67 (2001)

12. Y.J. Shi, T.T. Phipps, D. Colyer, Land Econ., 73, 90-100 (1997) doi: 10.2307/3147079

13. O.V. Mamai, I.N. Mamai, M.V. Kitaeva, Digital Age: Chances, Challenges and Future, 84, 359-365 (2020) 
14. K.A. Zhichkin, V.V. Nosov, V.I. Andreev, O.K. Kotar, L.N. Zhichkina, IOP Conf. Ser. Earth Environ. Sci., 341, 012005 (2019) doi:10.1088/1755-1315/341/1/012005

15. A. Tyutyunikov, A. Pashuta, T. Zakshevskaya, IOP Conf. Ser. Earth Environ. Sci., 274, 012012 (2019) doi: 10.1088/1755-1315/274/1/012012

16. J. Kilić, K. Rogulj, N. Jajac, CRORR, 10, 89-103 (2019) doi: 10.17535/crorr.2019.0009

17. A. Borchers, J. Ifft, T. Kuethe, Am. J. Agr. Econ., 96, 1307-1320 (2014) doi: 10.1093/ajae/aau041

18. B.A. Delbecq, Y.H. Kuethe, A.M. Borchers, Land Econ., 90, 587-600 (2014) doi: 10.3368/le.90.4.587

19. M.K. Awasthi, Land Use Policy, 39, 78-83 (2014) doi: 10.1016/j.landusepol.2014.04.002

20. K. Zhichkin, V. Nosov, L. Zhichkina, Zh. Dibrova, T. Cherepova, IOP Conf. Ser. Earth Environ. Sci., 315, 022023 (2019) doi:10.1088/1755-1315/315/2/022023

21. A.J. Plantinga, R.N. Lubowski, R.N. Stavins, J. Urban Econ., 52, 561-581 (2002) doi: 10.1016/S0094-1190(02)00503-X

22. O.R. Burt, Am. J. Agr. Econ., 68, 10-23 (1986) doi: 10.2307/1241645

23. C.T. Bastian, D.M. McLeod, M.J. Germino, W.A. Reiners, B.J. Blasko, Ecol. Econ., 40, 337-349 (2002) doi: 10.1016/S0921-8009(01)00278-6

24. D.F. Vitaliano, C. Hill, J. Real Estate Finance Econ., 8, 213-223 (1994) doi: 10.1007/BF01096992

25. A. Łakomiak, K. A. Zhichkin, J. Phys. Conf. Ser., 1399, 044088 (2019) doi:10.1088/1742-6596/1399/4/044088 